\title{
Biochar as adsorbent for removal of heavy metal ions [Cadmium(II), Copper(II), Lead(II), Zinc(II)] from aqueous phase
}

\author{
J. Komkiene ${ }^{1} \cdot$ E. Baltrenaite ${ }^{2}$
}

Received: 23 April 2014/Revised: 4 April 2015/Accepted: 19 July 2015/Published online: 4 August 2015

(C) Islamic Azad University (IAU) 2015

\begin{abstract}
The removal of the most prevalent heavy metal ions [cadmium(II), lead(II), copper(II), and zinc(II)] by adsorption on Scots pine (Pinus sylvestris L.) biochar and Silver birch (Betula pendula) biochar has been investigated, following the determination of physical and chemical adsorption properties of biochar. The efficiency of adsorption of heavy metal ions [cadmium(II), lead(II), copper(II), and zinc(II)] on biochar was studied at different concentrations of heavy metals [onefold maximum contaminant level, twofold maximum contaminant level, fivefold maximum contaminant level (in accordance with the requirements set out in the Water Framework Directive 2000/60/EC), dosages of biochar (1.6-140 g), and biochar types (Scots pine (P. sylvestris L.) biochar and Silver birch (B. pendula) biochar produced at slow and fast pyrolysis) at constant $\mathrm{pH}$ of leaching solution, temperature, and contact time. Adsorption capacity of Scots pine (P. sylvestris L.) biochar and Silver birch (B. pendula) biochar was assessed
\end{abstract}

J. Komkiene

julita.komkiene@gmail.com

1 Department of Environmental Protection, Vilnius Gediminas Technical University, Sauletekio al. 11, 10223 Vilnius, Lithuania

2 Department of Environmental Protection, Vilnius Gediminas Technical University, Sauletekio al. 11, SRK-II 303, 10223 Vilnius, Lithuania by the application of extended Freundlich isotherm. In this study, biochar was evaluated as a potential adsorbent to efficiently reduce concentration of heavy metal ions in metal-contaminated water. The maximum adsorption capacity were reached of copper(II) on Silver birch (B. pendula) biochar (128.7 $\left.\mu \mathrm{g} \mathrm{g}^{-1}\right)$ and of zinc(II) on Scots pine (P. sylvestris L.) biochar $\left(107.0 \mu \mathrm{g} \mathrm{g}^{-1}\right)$. Adsorption capacity of lead(II) on Silver birch (B. pendula) and Scots pine (P. sylvestris L.) biochar varied from 1.29 to 3.77 and from 2.37 to $4.49 \mu \mathrm{g} \mathrm{g}^{-1}$, respectively.

Keywords Adsorption process - Bioadsorbent - Extended Freundlich isotherm $\cdot$ Metal-contaminated water treatment

\section{Introduction}

Adsorption is widely used as effective physical method of separation in order to eliminate or lower the concentration of pollutants (organics and inorganics) in the polluted waters by application of most common adsorbents, such as silica gel, activated carbon, and aluminium oxide (Lin 1993). Biochar, as a potential adsorbent material, is a product of thermal decomposition of organic material under the limited supply of oxygen $\left(\mathrm{O}_{2}\right)$ at temperatures between 350 and $700{ }^{\circ} \mathrm{C}$ (Glaser et al. 2001). Celluloserich biomass waste from agriculture and forestry (such as plant residues, wood waste, peat, cattle manure and others) is used as a feedstock (EBC 2012). Due to the results of various studies in applications of biochar and such characteristics as porosity, high specific surface area, cation exchange capacity (Glaser et al. 2001; Downie et al. 2009), it would be perspective to develop biochar as a adsorbent material that can be efficiently used in metalpolluted water treatment. The urban storm water runoff 
treatment can be taken as an realistic example of biochar application for the removal of anthropogenic soluble heavy metals, which would reduce costs of storm water treatment by avoiding expensive materials (such as activated carbon, complexing agents for improve of removal performance) (Babel and Kurniawan 2003). It is mostly insignificant part of urban storm water runoff that has been treated before its release into receiving waters (Muthukrishnan 2006). Typical absence of treatment facility of urban storm water runoff can hardly assure the condition in which maximum heavy metal levels would not be exceeded. Heavy metals are not degradable (Shareef 2009) and the continuous increase in heavy metal contamination of estuaries and coastal waters (Kennish 1992) is a cause for concerns as these metals have the ability to bioaccumulate in tissues of various biotas and may also affect the distribution and density of benthic organisms (Shareef 2009). In different organisms' compartments, absorption of metals across cell walls involves mostly soluble metal ions (McGeer et al. 2004). Data of zinc and lead concentration in storm water runoff of 5-4880 and 2-493, respectively, provide information about threshold exceeding in countries of EU, USA, Switzerland, Australia (Göbel et al. 2007). Indicators of poor storm water runoff treatment represent that outlets of storm water runoff are derived directly to receiving waters without any treatment or that surface water treatment device is not working properly. Connecting the fact that in logging sites $70 \%$ of wood waste (including branches, chips, barks of trees) is left to rot, potentially wood waste biochar can be integrated in the management system of polluted water.

Wood biochar is suitable for possible use as adsorbent due to such properties as a predominant microporosity (from 10 to $3000 \mu \mathrm{m}$ ) and a specific surface area (from 5 to $600 \mathrm{~m}^{2} \mathrm{~g}^{-1}$ ) of produced wood biochar.

Overall aim of this study was to evaluate biochar as a potential adsorbent to reduce concentration of heavy metal ions in metal-contaminated water. The objectives of this study were to (1) compare physical properties (specific surface area, porosity, and bulk density) and chemical properties ( $\mathrm{pH}, \mathrm{CEC})$ of different types of biochar and evaluate which properties influenced metal adsorption more; (2) analyse the effects of the initial concentration of heavy metals, dosages of biochar, and biochar types on the adsorption of heavy metals on biochar; (3) evaluate adsorption capacity of biochar by applying extended Freundlich isotherm.

The experimental research was carried out in period of February-June, 2013, in Department of Environmental Protection of Vilnius Gediminas Technical University, and Scientific Institute of Thermal Insulation of Vilnius Gediminas Technical University, Lithuania.

\section{Materials and methods}

\section{Production of biochar}

Due to local availability, cost-effectiveness, and the prevalence of Scots pine (Pinus sylvestris L.) [occupies $44.2 \%$ of all trees by capacity $\left(\mathrm{m}^{3}\right)$ in Lithuania (State Forest Service under the Ministry of Environment of Lithuania 2013)] among coniferous trees and Silver birch (Betula pendula) [occupies $17.5 \%$ of all trees by capacity $\left(\mathrm{m}^{3}\right)$ in Lithuania (State Forest Service under the Ministry of Environment of Lithuania 2013)] among deciduous trees, these types of trees were selected from potentially clean areas as wood biomass materials for biochar production. Scots pine and Silver birch trees were selected by their similar age (which was determined by diameter of trees and by annual growth rings as bands of light and dark wood in extracted core of wood), avoiding defects in trees and risk of pollution (samples were taken at the distance of 100-150 m from any roads and $2000 \mathrm{~m}$ from any industrial pollution sources; the annual average concentrations of pollutants (PM; $\mathrm{CO} ; \mathrm{NO}_{2} ; \mathrm{SO}_{2}$; $\mathrm{C}_{6} \mathrm{H}_{6}$ ) in the ambient air did not exceed the limit values set out in the Air Quality Directive 2008/50/EC). The samples were extracted using Haglöf Sweden increment borer (length $300 \mathrm{~mm}$, core diameter $12 \mathrm{~mm}$ ). The bark was removed and the samples were transferred into plastic bags and later dried in the kiln SNOL4 at $(103 \pm 2){ }^{\circ} \mathrm{C}$ for $18 \mathrm{~h}$. Reweighed dry biomass was crushed into $1-2 \mathrm{~cm}$ long pieces. From each wood biomass, two types of biochar [under fast and slow pyrolysis process (Laird et al. 2011; Bruun 2011; Brownsort 2009)] were produced for further experiments. The wood biomass was separately shrink-wrapped into aluminium foil (Saleh et al. 2012) then transferred into muffle furnace E5CK-T and pyrolysed under limited $\mathrm{O}_{2}$ conditions:

- at the temperature of $(450 \pm 5){ }^{\circ} \mathrm{C}$ for $120 \mathrm{~min}$ (slow pyrolysis);

- at the temperature of $(700 \pm 5){ }^{\circ} \mathrm{C}$ for $45 \mathrm{~min}$ (fast pyrolysis).

Four types of biochar samples were produced: (1) Scots pine biochar produced at conditions of slow pyrolysis; (2) Scots pine biochar produced at conditions of fast pyrolysis; (3) Silver birch biochar produced at conditions of slow pyrolysis; and (4) Silver birch biochar produced at conditions of fast pyrolysis. All samples were crushed into pieces of 1-10 mm using grinder after being cooled down to ambient temperature $\left(20 \pm 3{ }^{\circ} \mathrm{C}\right)$.

\section{Physical properties of biochar}

Determination of bulk density was based on dry matter weight and the occupied volume ratio (Kathleen et al. 
1992) using an analytical and precision balances KERN 770/GS/GJ.

The porosity, as well as the specific pore area, of Scots pine and Silver birch biochar was determined at Scientific Institute of Thermal Insulation of Vilnius Gediminas Technical University using mercury porosimeter Quantachrome Poremaster PM-33-12, which can establish a broader pore size distribution more quickly and accurately than other methods (Giesche 2006).

\section{Chemical properties of biochar}

For the purpose of the determination of concentrations of heavy metals in biochar, dried biochar samples were fired at $450{ }^{\circ} \mathrm{C}$ for $3 \mathrm{~h}$ to ashes. To dissolve ashes by acids, each $0.1 \mathrm{~g}$ of ash sample was mixed with $3 \mathrm{~mL}$ of $\mathrm{HNO}_{3}(65 \%)$ and $9 \mathrm{~mL}$ of $\mathrm{HCl}(37 \%)$ and poured into special vessels, which were then placed into Milestone ETHOS digester and heated for $45 \mathrm{~min}$. The solution was then poured into 50-mL flask and diluted with deionised water to reach the mark of $50 \mathrm{~mL}$ (Pundyte et al. 2011). The concentrations of heavy metals in the samples were determined by the atomic absorption spectrophotometer Buck Scientific's 210VGP.

$\mathrm{pH}$ was determined by an instrumental method using a glass electrode in a 1:5 (volume fraction) suspension of biochar in deionized water. After shaking the mixture of biochar for $1 \mathrm{~h}$ and after allowing deionized water to stand for $1 \mathrm{~h}$, the $\mathrm{pH}$ was measured using Mettler Toledo Seven Multi pH meter (Pundyte et al. 2011).

CEC was determined using ammonium acetate (Nguyen and Lehmann 2009; Lehman et al. 2011; Nigussie et al. 2012; Aston et al. 2013). Twenty-five grams of biochar was allowed to stand overnight after being thoroughly shaken with $125 \mathrm{~mL}$ of $1 \mathrm{M} \mathrm{NH}_{4} \mathrm{OAc}$. The biochar was transferred in filter paper-fitted Buchner funnel. The biochar was gently washed four times with $25 \mathrm{~mL}$ additions of $\mathrm{NH}_{4}$ OAc, allowing each addition to filter through. The leachate was discarded and the biochar was washed with eight separate additions of $95 \% \mathrm{CH}_{3} \mathrm{CH}_{2} \mathrm{OH}$ to remove excess saturating solution. The adsorbed $\mathrm{NH}_{4}$ was extracted by leaching the biochar with $1 \mathrm{M} \mathrm{KCl}$. The biochar was discarded and the leachate was transferred to a volumetric flask to dilute to $250 \mathrm{~mL}$ volume with additional $\mathrm{KCl}$. The concentration of $\mathrm{NH}_{4}-\mathrm{N}$ was determined in the $\mathrm{KCl}$ extract by colorimetry (from composed ammonia calibration curve by measuring absorption intensity at $\lambda=400 \mathrm{~nm}$ with photocolorimeter in $1 \mathrm{~cm}$ length cells, concentration of $\mathrm{NH}_{4}-\mathrm{N}$ was calculated using Nessler method (Tan et al. 2012). Also $\mathrm{NH}_{4}-\mathrm{N}$ was determined in the original $\mathrm{KCl}$ extracting solution (blank) to adjust for possible $\mathrm{NH}_{4}-\mathrm{N}$ contamination in this reagent. Cation exchange capacity was calculated using Eq. (1):
$\mathrm{CEC}=\left(\mathrm{NH}_{4}-\mathrm{N}_{\text {inextract }}-\mathrm{NH}_{4}-\mathrm{N}_{\text {inblank }}\right) / 14$

where CEC — cation exchange capacity, $\mathrm{cmol}_{\mathrm{c}} \mathrm{kg}^{-1} ; \mathrm{NH}_{4}-$ $\mathrm{N}_{\text {in extract }}$-ammonium ion concentration in the extract, $\mathrm{mg} \mathrm{L}^{-1} ; \mathrm{NH}_{4}-\mathrm{N}_{\text {in blank }}$-ammonium ion concentration in the blank, $\mathrm{mg} \mathrm{L}^{-1}$. Biochar with the largest CEC was chosen for further column test.

The pore diameter and length of Scots pine and Silver birch biochar samples were determined by the scanning electron microscope (SEM) JEOL JSM-7600F.

Total carbon (TC) was determined using equipment TOC-V by SHIMADZU. Samples were dried at room temperature, sieved through a $2-\mathrm{mm}$ sieve, crushed, and homogenized. $1 \mathrm{mg}$ of sample weighed in the combustion cell was placed in the combustion chamber.

\section{Leaching solution and column test set-up}

The leaching solutions used corresponded to the composition with onefold, twofold, and fivefold value of maximum contaminant level (MCL) for selected heavy metals ions [Cd(II), $\mathrm{Pb}$ (II), $\mathrm{Cu}(\mathrm{II}), \mathrm{Zn}(\mathrm{II})]$ in water, which is discharged to receiving waters (Table 1) in accordance with the requirements set out in the Water Framework Directive 2000/60/EC. The leaching solution was prepared by dissolving metal salts $\left(\mathrm{CdSO}_{4} \cdot 8 / 3 \mathrm{H}_{2} \mathrm{O} ; \quad \mathrm{Pb}\left(\mathrm{NO}_{3}\right)_{2}\right.$; $\mathrm{Cu}\left(\mathrm{NO}_{3}\right)_{2} \cdot 3 \mathrm{H}_{2} \mathrm{O}$; and $\left.\mathrm{Zn}\left(\mathrm{NO}_{3}\right)_{2} \cdot 6 \mathrm{H}_{2} \mathrm{O}\right)$ into deionized water. The leaching solutions were prepared with $0.1 \mathrm{M}$ $\mathrm{NaOH}$ to adjust $\mathrm{pH}$ to $7.5 \pm 0.02$.

Seven experimental columns in compliance with ISO 21268-3 were made of organic glass with internal diameter of $56 \mathrm{~mm}$ and height of $50 \mathrm{~cm}$ and fitted with plastic filters at the bottom in order to prevent the grains passing through (Fig. 1). In the top part of the column, a thin layer of non-reactive rubber material is applied to ensure proper water flow over the width of the column (Mihaljevic et al. 2004).

In order to model the biochar adsorption capacity using Freundlich isotherm and to compare adsorption capacity between different types of biochar, each column was filled with a different dose of biochar. Different types of biochar fitted-bed filled the columns with mass ratio 1:2.5:5:10:25:50:100 of biochar.

Table 1 Concentrations of heavy metals ions in leaching solutions

\begin{tabular}{llll}
\hline $\begin{array}{l}\text { Heavy } \\
\text { metal ions }\end{array}$ & $\begin{array}{l}\text { Onefold MCL } \\
\left(\mathrm{mg} \mathrm{L}^{-1}\right)\end{array}$ & $\begin{array}{l}\text { Twofold MCL } \\
\left(\mathrm{mg} \mathrm{L}^{-1}\right)\end{array}$ & $\begin{array}{l}\text { Fivefold MCL } \\
\left(\mathrm{mg} \mathrm{L}^{-1}\right)\end{array}$ \\
\hline $\mathrm{Cd}(\mathrm{II})$ & 0.04 & 0.08 & 0.2 \\
$\mathrm{~Pb}(\mathrm{II})$ & 0.1 & 0.2 & 0.5 \\
$\mathrm{Cu}$ (II) & 0.5 & 1.0 & 2.5 \\
$\mathrm{Zn}(\mathrm{II})$ & 0.4 & 0.8 & 2.0 \\
\hline
\end{tabular}




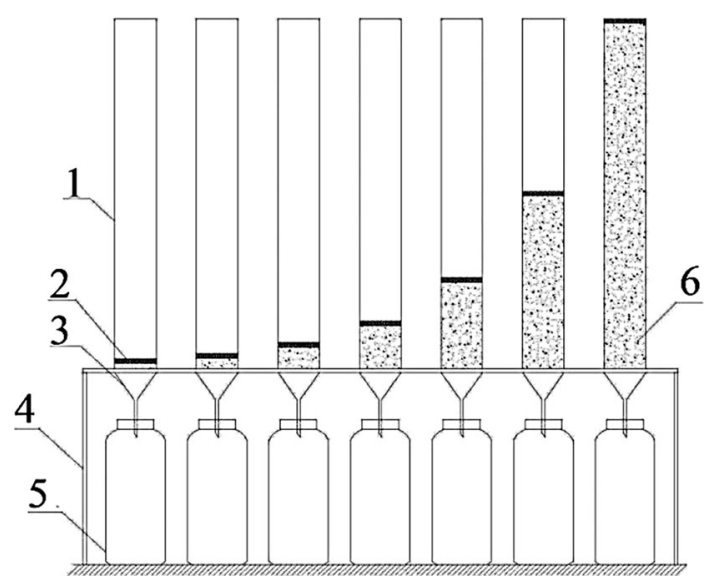

Fig. 1 Stand for a column leaching test: 1 organic glass cylinder, 2 non-reactive material, 3 analytic funnel, 4 wooden frame, $51000-\mathrm{mL}$ HDPE bottle, 6 biochar fitted-bed

Each of seven columns was filled with different dose of Scots pine biochar produced at fast pyrolysis conditions (due to high specific surface area), and then $1000 \mathrm{~mL}$ of leaching solution was applied to each column at constant $\mathrm{pH}$ (7.5) of leaching solution, temperature $\left(23 \pm 2{ }^{\circ} \mathrm{C}\right.$ in laboratory), and contact time (15-20 s). Column experiment was repeated twice with different initial concentrations of heavy metals. Then, columns were filled with the same dose of Silver birch biochar sample produced under fast pyrolysis (due to the high cation exchange capacity), and the process of filtration was repeated. High density polyethylene bottles with an appropriate volume of $1 \mathrm{~L}$, and with a screw cap, for eluate collection, transportation, and preservation of eluate samples were used.

The leachate solutions obtained were filtered using qualitative filter paper with particle retention of 5-13 $\mu \mathrm{m}$. $\mathrm{pH}$ was determined (ISO 10523:2008) immediately after taking the samples (Mihaljevic et al. 2004). Concentrations of heavy metal ions $(\mathrm{Cd}, \mathrm{Pb}, \mathrm{Cu}, \mathrm{Zn})$ were determined by flame atomic absorption spectrophotometer (FAAS) (Pundyte et al. 2011).

\section{Adsorption efficiency}

Adsorption efficiency was calculated using Eq. (2):

$E=\left(1-\frac{C_{\text {final }}}{C_{\text {initial }}}\right) \times 100 \%$

where $E$-adsorption efficiency, $\%$; $C_{\text {final }}$-the concentration of heavy metal in eluate, $\mathrm{mg} \mathrm{L}^{-1} ; C_{\text {initial }}$-the concentration of heavy metal in solution, $\mathrm{mg} \mathrm{L}^{-1}$.

\section{Adsorption isotherm}

Adsorption process is mathematically expressed by adsorption isotherms. The adsorption capacity and intensity of heavy metals on biochar has been evaluated by applying Freundlich isotherm. The capacity is defined as Eq. (3):

$X / M=K \times C_{f}^{\frac{1}{n}}$

where $X / M$-the amount of adsorbed pollutant per unit mass of biochar, $\mathrm{mg} \mathrm{g}^{-1} ; K$-constant, capacity of the biochar for the adsorbate; $C_{f}$-the solute equilibrium concentration, $\mathrm{mg} \mathrm{L}^{-1} ; \frac{1}{n}$ function of the intensity of adsorption.

To evaluate $K$ and $\frac{1}{n}$, the mass of removed solute was expressed as the difference between the original and final concentrations, where $X$ is $C_{0}-C_{f}$. After performing a linear regression on the logarithmic data, the intercept $K$ and the slope $\frac{1}{n}$ were determined through the produced equation (Thavamani and Rajkumar 2013). Extended Freundlich isotherm is widespread due to its accuracy and is recommended for most cases of multi-component adsorption. Freundlich constants were determined using the linear form of the equation for the calculation of the experimental data. The expressions for four-component adsorption system are obtained as Eqs. (4-7):

$$
\begin{gathered}
q_{a}=\frac{K_{a} C_{f a}^{\frac{1}{n_{a}}+\frac{1}{n_{b}}+\frac{1}{n_{c}}+\frac{1}{n_{d}}}}{K_{a} C_{f a}^{\frac{1}{n_{a}}}+K_{b} C_{f b}^{\frac{1}{n_{b}}}+K_{c} C_{f c}^{\frac{1}{n_{c}}}+K_{d} C_{f d}^{\frac{1}{n_{d}}}} \\
q_{b}=\frac{K_{b} C_{f b}^{\frac{1}{n_{a}}+\frac{1}{n_{b}}+\frac{1}{n_{c}}+\frac{1}{n_{d}}}}{K_{a} C_{f a}^{\frac{1}{n_{a}}}+K_{b} C_{f b}^{\frac{1}{n_{b}}}+K_{c} C_{f c}^{\frac{1}{n_{c}}}+K_{d} C_{f d}^{\frac{1}{n_{d}}}} \\
q_{c}=\frac{K_{c} C_{f c}^{\frac{1}{n_{a}}+\frac{1}{n_{b}}+\frac{1}{n_{c}}+\frac{1}{n_{d}}}}{K_{a} C_{f a}^{\frac{1}{n_{a}}}+K_{b} C_{f b}^{\frac{1}{n_{b}}}+K_{c} C_{f c}^{\frac{1}{n_{c}}}+K_{d} C_{f d}^{\frac{1}{n_{d}}}} \\
q_{d}=\frac{K_{d} C_{f d}^{\frac{1}{n_{a}}+\frac{1}{n_{b}}+\frac{1}{n_{c}}+\frac{1}{n_{d}}}}{K_{a} C_{f a}^{\frac{1}{n_{a}}}+K_{b} C_{f b}^{\frac{1}{n_{b}}}+K_{c} C_{f c}^{\frac{1}{n_{c}}}+K_{d} C_{f d}^{\frac{1}{n_{d}}}}
\end{gathered}
$$

\section{Statistical analysis and quality assurance of experiments}

Each analysis was prepared and analysed in duplicates. The measurements were carried out three times and the average of the results of measurement errors was calculated. The statistical analysis was performed using Excel program. The results of arithmetic mean values with values of standard deviation were presented in graphical expression of the results. The standards of calibration are used to calibrate devices in each year.

The quality of experiments was assured by blank samples such as deionized water (in determination of concentration of $\mathrm{NH}_{4}-\mathrm{N}$ ), $\mathrm{KCl}$ (in determination of $\mathrm{pH}$ ), and determination of heavy metals in leaching solution before the elution. 


\section{Results and discussion}

\section{Reduction in biomass weights during the production process of biochar}

Different conditions of pyrolysis process (such as temperature and duration of thermal treatment) and the wood biomass type influence the reduction in mass (Downie et al. 2009) from Scots pine- and Silver birch-produced biochar. The proportions of produced biochar, liquid and gas, can be modified by changing the rate of heating and final temperature.

The average moisture content of fresh heartwood and fresh sapwood depends on species and seasonal variations (Glass and Zelinka 2010). Moisture content of Scots pine sample was $49.11 \%$, Silver birch-70.01\%.

The weight of dry Scots pine biomass and Silver birch biomass decreased from 4.63 to 6.00 times in the production of biochar under fast pyrolysis conditions, while the weight of dry Scots pine biomass and Silver birch biomass decreased from 3.74 to 4.21 times in the production of biochar under slow pyrolysis conditions. Weight of biomass, heat-treated in fast pyrolysis conditions, decreased from 0.89 to 1.79 times more than the weight of biomass, heat-treated in slow pyrolysis conditions. When the heat treatment temperature was $(700 \pm 5){ }^{\circ} \mathrm{C}$, the biochar yield reduced more than at conditions of slow pyrolysis due to increase of aromatization of biochar (Sadaka and Negi 2009; Overend 2008).

\section{Surface characterization}

The SEM images (Fig. 2) indicated that Scots pine and Silver birch biochar samples consisted of large (40-80) $\mu \mathrm{m}$ and small (5-10) $\mu \mathrm{m}$ diameter pores, which were either located in layers (in case of Scots pine biochar) or small diameter pore layers separated by large diameter pore rows (in case of Silver birch biochar). Pore length was much greater than its diameter and not $<1000 \mu \mathrm{m}$.

Scanning electron microscope imaging showed that heat-treated wood retains its original wood pores structure. Due to accumulation of charge on the surface of the sample, blurry images (Fig. 2a, b) were produced.

The porosity of Scots pine biochar samples was less dependent on the temperature of treatment. Porosity of Scots pine biochar samples was very insignificantly different. The sample of the highest porosity in slow pyrolysis of Silver birch was $8.4 \%$ more porous than the highest of the fast pyrolysis (Table 2). The specific surface area increased with increased temperatures of thermal treatment (Table 2). However, the temperature at which deformation occurred was potentially reached and specific surface area
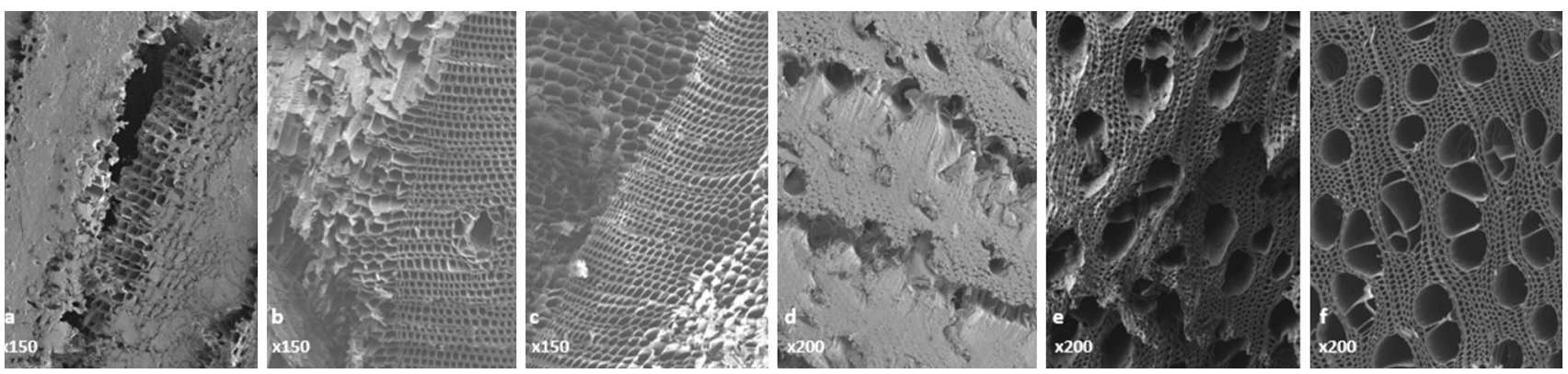

Fig. 2 SEM images of feedstock and biochar: a Scots pine before pyrolysis, $\mathbf{b}$ slow pyrolysis Scots pine, $\mathbf{c}$ fast pyrolysis Scots pine, $\mathbf{d}$ Silver birch feedstock, e slow pyrolysis Silver birch, $\mathbf{f}$ fast pyrolysis Silver birch

Table 2 Physical and chemical properties of samples of biochar \pm SD

\begin{tabular}{|c|c|c|c|c|c|c|c|c|c|c|}
\hline $\begin{array}{l}\text { Biochar } \\
\text { sample }\end{array}$ & $\begin{array}{l}\text { Temperature } \\
\text { of thermal } \\
\text { treatment } \\
\left({ }^{\circ} \mathrm{C}\right)\end{array}$ & $\begin{array}{l}\text { Thermal } \\
\text { treatment } \\
\text { duration } \\
\text { (min) }\end{array}$ & $\begin{array}{l}\text { Porosity } \\
(\%)\end{array}$ & $\begin{array}{l}\text { Specific } \\
\text { surface } \\
\text { area } \\
\left(\mathrm{m}^{2} \mathrm{~g}^{-1}\right)\end{array}$ & $\begin{array}{l}\text { Density } \\
\left(\mathrm{g} \mathrm{cm}^{-3}\right)\end{array}$ & $\begin{array}{l}\text { Apparent } \\
\text { density } \\
\left(\mathrm{g} \mathrm{cm}^{-3}\right)\end{array}$ & $\begin{array}{l}\text { Bulk } \\
\text { density } \\
\left(\mathrm{g} \mathrm{cm}^{-3}\right)\end{array}$ & $\mathrm{pH}$ & $\begin{array}{l}\text { CEC } \\
\left(\mathrm{cmolc} \mathrm{kg}^{-1}\right)\end{array}$ & $\mathrm{TC}(\%)$ \\
\hline \multirow{2}{*}{$\begin{array}{l}\text { Scots pine } \\
\text { (Pinus } \\
\text { sylvestris } \\
\text { L.) }\end{array}$} & $450( \pm 5)$ & 120.0 & 77.4 & 9.16 & 0.275 & 0.520 & 1.21 & $8.56 \pm 0.02$ & $3.41 \pm 0.24$ & $96.3 \pm 0.01$ \\
\hline & $700( \pm 5)$ & 45.0 & 77.3 & 10.4 & 0.279 & 0.499 & 1.23 & $8.52 \pm 0.01$ & $2.40 \pm 0.21$ & $95.8 \pm 0.01$ \\
\hline \multirow{2}{*}{$\begin{array}{l}\text { Silver birch } \\
\text { (Betula } \\
\text { pendula) }\end{array}$} & $450( \pm 5)$ & 120.0 & 79.2 & 5.92 & 0.444 & 0.804 & 2.14 & $8.69 \pm 0.02$ & $5.09 \pm 0.42$ & $95.0 \pm 0.01$ \\
\hline & $700( \pm 5)$ & 45.0 & 73.1 & 7.17 & 0.453 & 0.682 & 1.68 & $9.27 \pm 0.01$ & $5.71 \pm 0.07$ & $96.6 \pm 0.01$ \\
\hline
\end{tabular}


was subsequently lost. Pore structure of Silver birch biochar samples was significantly different from that of the Scots pine biochar samples. Both the porosity and pore surface area were smaller.

\section{pH of eluates}

Most aquatic biota is sensitive to $\mathrm{pH}$ variations; fish reduction and change in other species occur when the $\mathrm{pH}$ is altered outside their tolerance limits (Novotny and Olem 1994). Even the $\mathrm{pH}$ of acid rain water is lower than 7; in discharges of urban storm water runoff, $\mathrm{pH}$ usually is slightly alkaline (in range of 7.49-8.19 (Adedeji and Olayinka 2013; Milukaite et al. 2010; Kaminskas 2012; Eiviene and Tricys 2011)) due to in-built environment-used detergents and soap-based products. In urban areas, cementitious porous pavement appears as a passive unit operation for storm water runoff acid neutralization (Kuang and Sansalone 2011). Due to higher $\mathrm{pH}$ of Scots pine biochar, $\mathrm{pH}$ of eluate resulted from elution through Silver birch biochar slightly increased more than $\mathrm{pH}$ of eluate resulted from elution through Scots pine biochar (Fig. 3).

Highly alkaline biochar could increase $\mathrm{pH}$ of treating water above the limits (according to international standards, $\mathrm{pH}$ of treated effluent water (including storm water runoff) should access the limits of 6.5-8.5).

The carbon fraction of the biochar acted as a weak alkali and partially buffered the $\mathrm{pH}$ of the system. Raising the $\mathrm{pH}$ made toxic metals less soluble, and adsorbing the positively charged metal ions removed them from the solution.

\section{Effect of an initial heavy metal concentration}

The effect of initial heavy metal concentration on adsorption of heavy metals by two types of biochar is shown in Fig. 4.

The temperature, contact time, $\mathrm{pH}$, dosage of biochar fixed-bed were kept the same. When the concentration of heavy metals increased, available adsorption sites were occupied, and, as the result, it was followed by decrease in adsorption efficiency (Thavamani and Rajkumar 2013).

Though the specific surface area of Scots pine biochar was 1.45 times higher than that of Silver birch biochar, the higher efficiency of adsorption of heavy metals on Silver birch biochar was easily noticeable. It is possibly due to 2.38 time higher cation exchange capacity of Silver birch biochar than cation exchange capacity of Scots pine biochar.
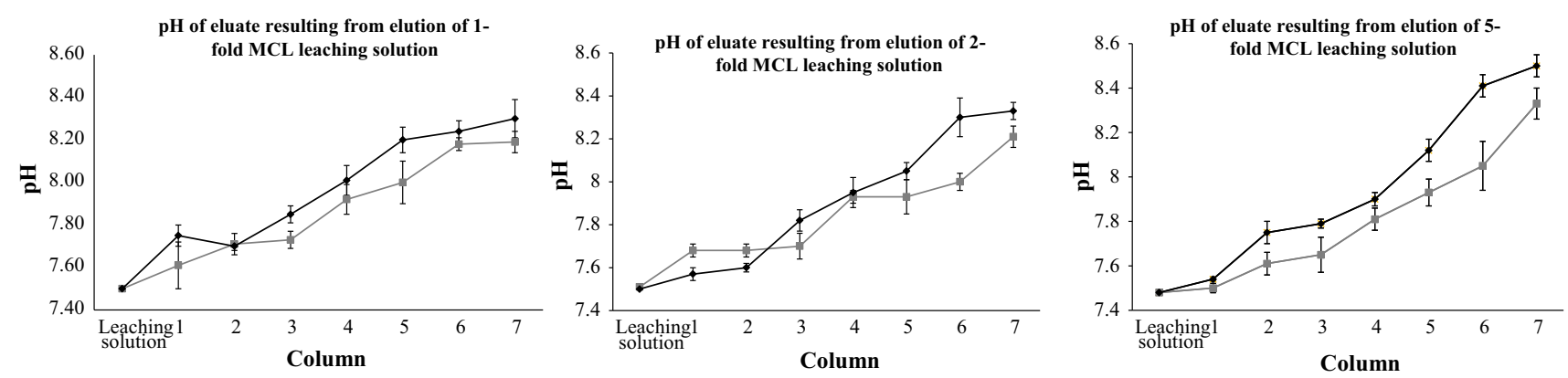

$-\mathrm{pH}$ of eluate resulting from elution through Scots pine (Pinus sylvestris L.)
biochar

$\rightarrow$ pH of eluate resulting from elution through Silver birch (Betula pendula)

Fig. 3 The influence of alkaline biochars on the $\mathrm{pH}$ of eluates. Values are mean $\pm \mathrm{SD}$ (vertical lines)

Fig. 4 Effects of initial metal concentration on adsorption (\%) of heavy metals on: a Scots pine biochar, b Silver birch biochar. Values are mean $\pm \mathrm{SD}$ (vertical lines)
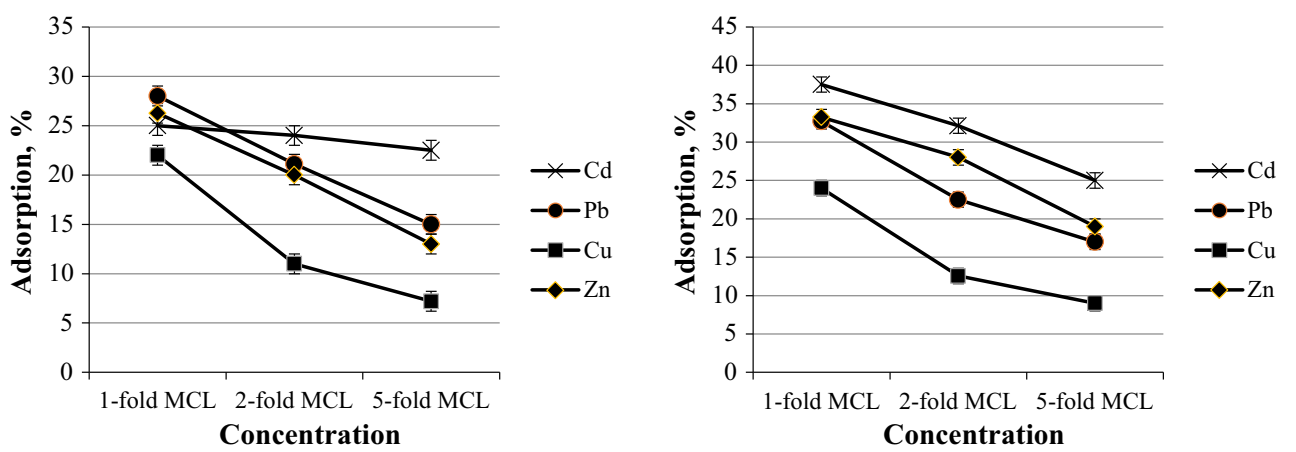
Fig. 5 Effects of biochar (produced at fast pyrolysis conditions) dosage on adsorption of heavy metals on: a Scots pine biochar, b Silver birch biochar. Values are mean $\pm \mathrm{SD}$ (vertical lines)

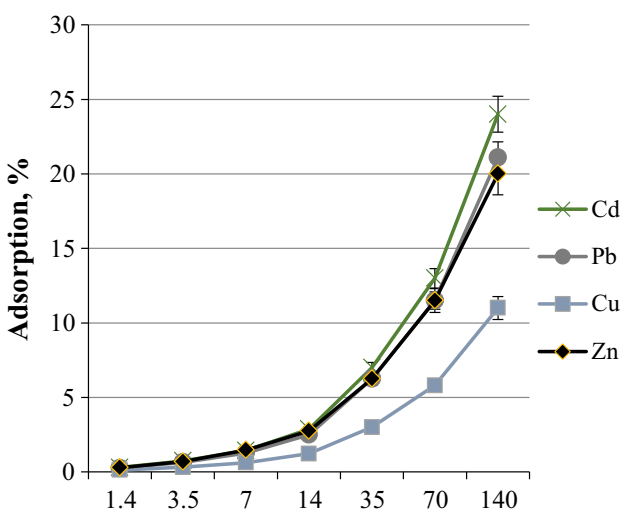

(a) Dosage of Scots pine biochar, g

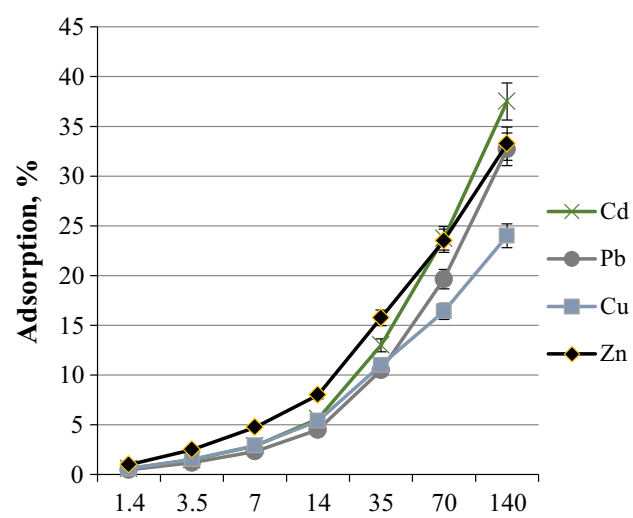

(b) Dosage of Silver birch biochar, $g$

\section{Effect of biochar dosage}

The effect of dosages of two different types of biochar on adsorption of heavy metals is shown in Fig. 5. The temperature, contact time, $\mathrm{pH}$, and initial concentration of heavy metals were kept constant. The adsorption of heavy metals increased, when the dosage of adsorbent increased. The increase of specific surface area of an adsorbent was followed by the increases of the number in sites available for adsorption (Thavamani and Rajkumar 2013).

\section{Adsorption isotherm}

Freundlich isotherm was used to represent adsorption of heavy metals from metal-contaminated solution on biochar. The curvature and steepness of the isotherm is determined by $K_{f}$ and $n$ (Low and Lee 2000). The affinity of the adsorbent towards the uptake of heavy metal ion is indicated by the value of $n$ (Dada et al. 2013): when $n=1$, partition between the two phases is independent of the concentration; when $1 / n<1$, normal adsorption occurs; when $1 / n>1$, cooperative adsorption occurs (Mohan and Karthikeyan 1997). When value of $n$ is in range between unity and ten, adsorption process is favourable (Goldberg 2005). A linear regression on the logarithmic data (Fig. 6) produced the equations in plots [e.g., Eq. (8)]. Using the equation, parameters were calculated:

$y=0.9052 x+1.1783$

$\ln K=1.178$

$K=3.249$

$1 / n=0.905$

$n=1.1$

The value of $n=1.1$ indicated the favourableness of the adsorption of $\mathrm{Zn}(\mathrm{II})$ onto Silver birch biochar.

The approximate indicators of the adsorption capacity $K$ and the adsorption intensity $n$ of all isotherm equations are shown in Table 3.
The values of $n>1$ indicated the degree of nonlinearity between solution concentration and adsorption as physical process (Desta 2013). In all cases, $n$ is between one and ten (Table 3), so the adsorption process was favourable. $R^{2}$ values confirm that the Freundlich isotherms fitted the experiments. The higher adsorption capacity of Silver birch biochar was more frequently than adsorption capacity of Scots pine biochar.

The expressions in general form for four-metal adsorption system were obtained in Eqs. (9-12):

$$
\begin{gathered}
q_{C d}=\frac{K_{C d} C_{C d}^{\frac{1}{n_{C d}}+\frac{1}{n_{C u}}+\frac{1}{n_{P b}}+\frac{1}{n_{Z n}}}}{K_{C d} C_{C d}^{\frac{1}{n_{C d}}}+K_{C u} C_{C u}^{\frac{1}{n_{C u}}}+K_{P b} C_{P b}^{\frac{1}{n_{P b}}}+K_{Z n} C_{Z n}^{\frac{1}{n_{Z n}}}} \\
q_{P b}=\frac{K_{P b} C_{P b}^{\frac{1}{n_{P d}}+\frac{1}{n_{C u}}+\frac{1}{n_{P b}}+\frac{1}{n_{Z n}}}}{K_{C d} C_{C d}^{\frac{1}{n_{C l}}}+K_{C u} C_{C u}^{\frac{1}{n_{C u}}}+K_{P b} C_{P b}^{\frac{1}{n_{P b}}}+K_{Z n} C_{Z n}^{\frac{1}{n_{Z n}}}} \\
q_{C u}=\frac{K_{C u} C_{C u}^{\frac{1}{n_{n}}}+\frac{1}{n_{C u}}+\frac{1}{n_{P b}}+\frac{1}{n_{Z n}}}{K_{C d} C_{C d}^{\frac{1}{n_{C d}}}+K_{C u} C_{C u}^{\frac{1}{n_{C u}}}+K_{P b} C_{P b}^{\frac{1}{n_{P b}}}+K_{Z n} C_{Z n}^{\frac{1}{n_{Z n}}}} \\
q_{Z n}=\frac{K_{Z n} C_{Z n}^{\frac{1}{n_{C d}}+\frac{1}{n_{C u}}+\frac{1}{n_{P b}}+\frac{1}{n_{Z n}}}}{K_{C d} C_{C d}^{\frac{1}{n_{C d}}}+K_{C u} C_{C u}^{\frac{1}{n_{C u}}}+K_{P b} C_{P b}^{\frac{1}{n_{P b}}}+K_{Z n} C_{Z n}^{\frac{1}{n_{Z n}}}}
\end{gathered}
$$

where $q_{C d}, q_{C u}, q_{P b}, q_{Z n}$-the amount of adsorbed heavy metal per unit mass of biochar, $\mathrm{mg} \mathrm{g}^{-1} ; K_{C d}, K_{P b}, K_{C u}, K_{Z n}-$ capacity of the biochar for the heavy metal; $C_{C d}, C_{C u}, C_{P b}$, $C_{Z n}$-the pollutant equilibrium concentration, $\mathrm{mg} \mathrm{L}^{-1}$; $\frac{1}{n_{C d}}, \frac{1}{n_{C u}}, \frac{1}{n_{P b}}, \frac{1}{n_{Z n}}$ function of the intensity of adsorption.

Maximum adsorption capacity of $\mathrm{Cd}(\mathrm{II})$ on Scots pine biochar at concentration of twofold value of MCL was 0.65 and 2.4 times higher than at concentration of onefold and fivefold value of MCL, respectively. Comparing adsorption capacity of Cd(II) on Silver birch biochar, the differences were slighter: only 6 and $4 \%$ higher than at concentration of onefold and fivefold value of MCL, respectively. Adsorption capacity of $\mathrm{Pb}$ (II) on Silver birch and Scots pine biochar varied $\quad 1.29-3.77 \mu \mathrm{g} \mathrm{g}^{-1}$ and $2.37-4.49 \mu \mathrm{g} \mathrm{g}^{-1}$, 
respectively. The maximum adsorption capacity were reached of $\mathrm{Cu}$ (II) on Silver birch biochar $\left(128.7 \mu \mathrm{g} \mathrm{g}^{-1}\right)$ and of $\mathrm{Zn}$ (II) on Scots pine biochar $\left(107.0 \mu \mathrm{g} \mathrm{g}^{-1}\right)$.

The most frequently selectivity sequence of heavy metal ions adsorption on Scots pine biochar: $\mathrm{Cd}(\mathrm{II})>\mathrm{Pb}(\mathrm{II})>\mathrm{Z}$ $\mathrm{n}(\mathrm{II})>\mathrm{Cu}(\mathrm{II})$; and the selectivity sequence of heavy metal ions adsorption on Silver birch biochar: $\mathrm{Cd}(\mathrm{II})>\mathrm{Zn}(\mathrm{II})>\mathrm{P}$ $\mathrm{b}(\mathrm{II})>\mathrm{Cu}$ (II). In the sequence, each heavy metal, which was to the left of the previous one, had the higher adsorption selectivity than that one to the right. The adsorption of $\mathrm{Cd}(\mathrm{II})$ on both types of biochar was optimum, the adsorption of $\mathrm{Cu}(\mathrm{II})$ on both types of biochar was the
Fig. 6 Freundlich isotherms of heavy metals on Silver birch biochar (filledsquare) and Scots pine biochar (filled triangle), when leaching solution composition is with: a onefold value of MCL, $\mathbf{b}$ twofold value of MCL, $\mathbf{c}$ fivefold value of MCL
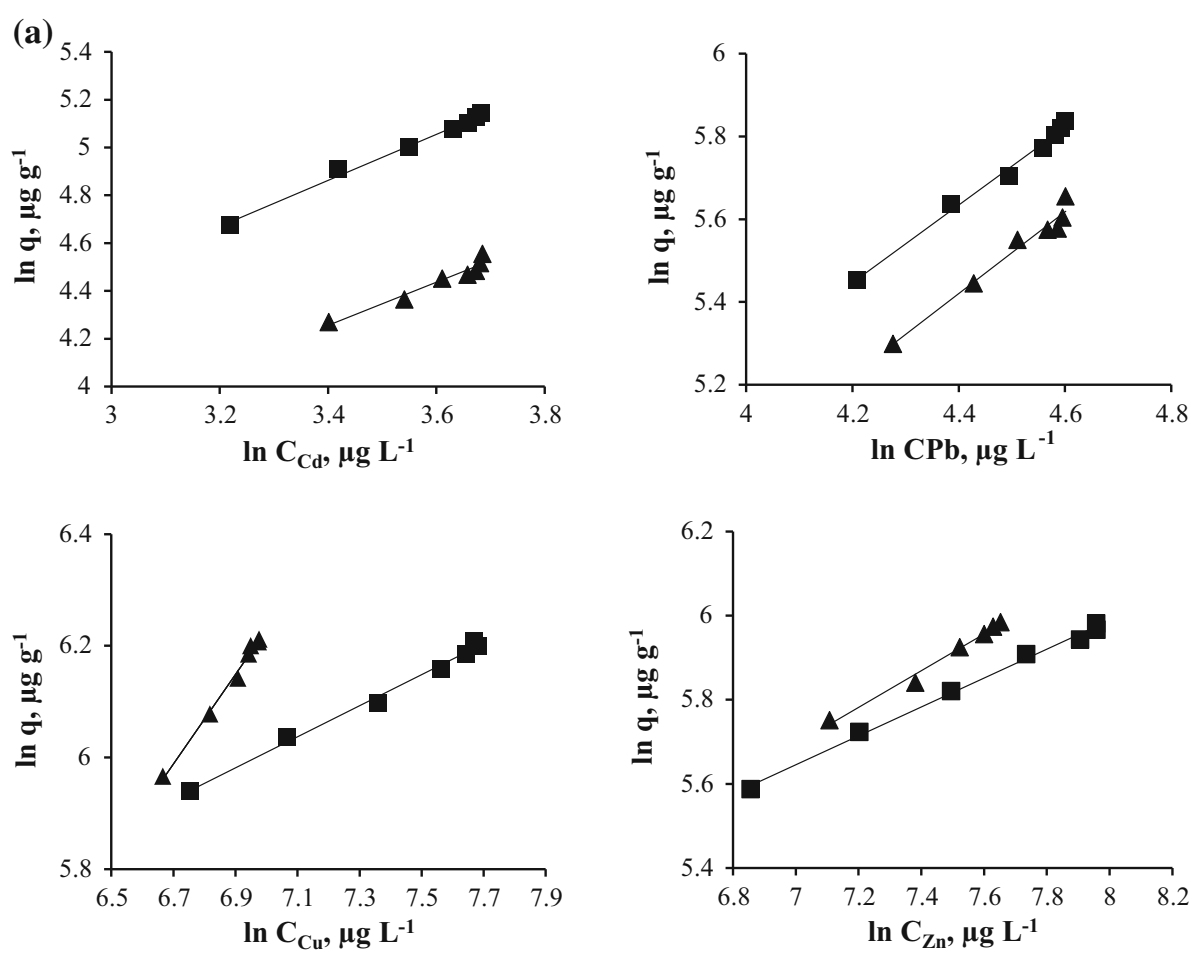

(b)
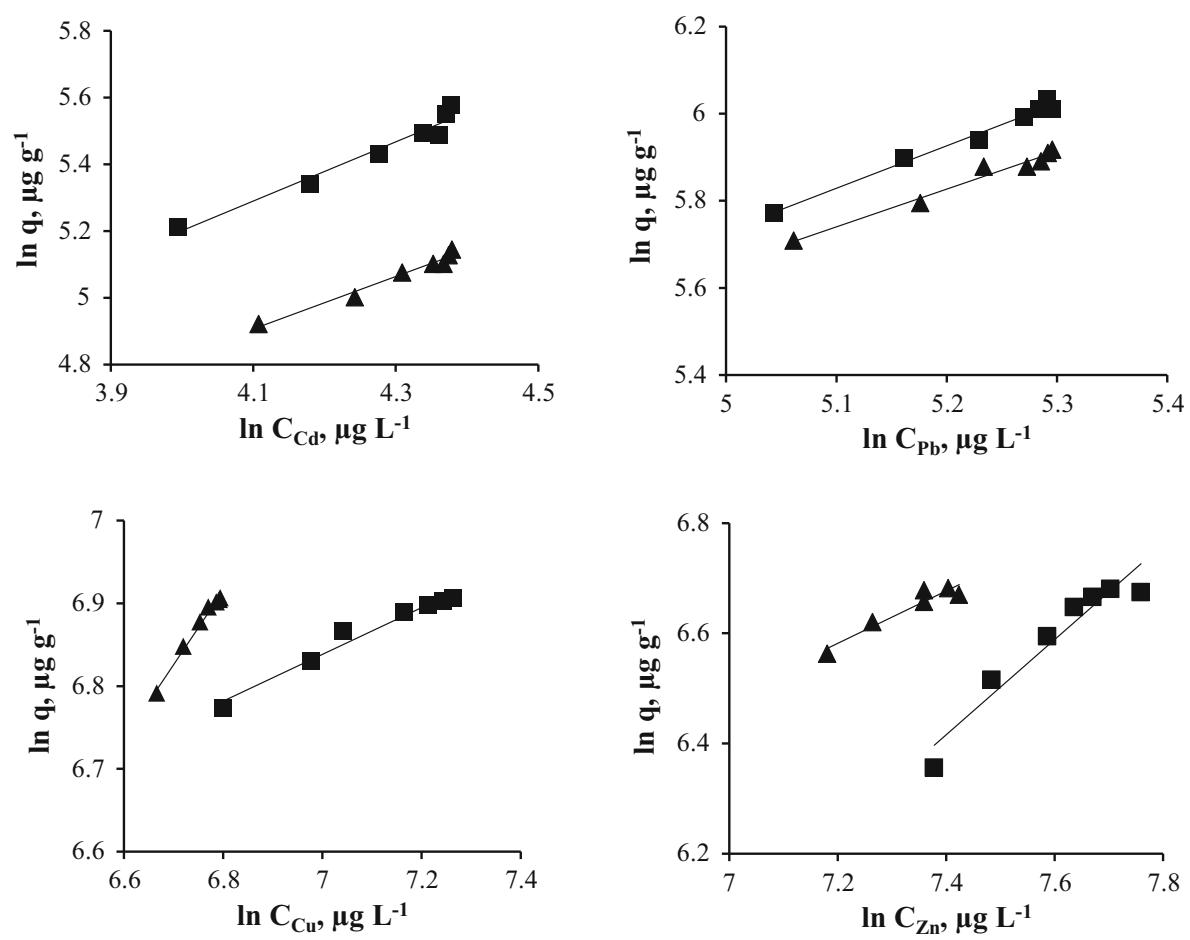

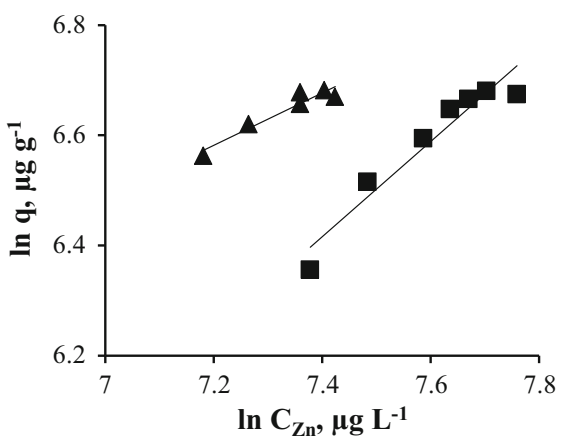


Fig. 6 continued
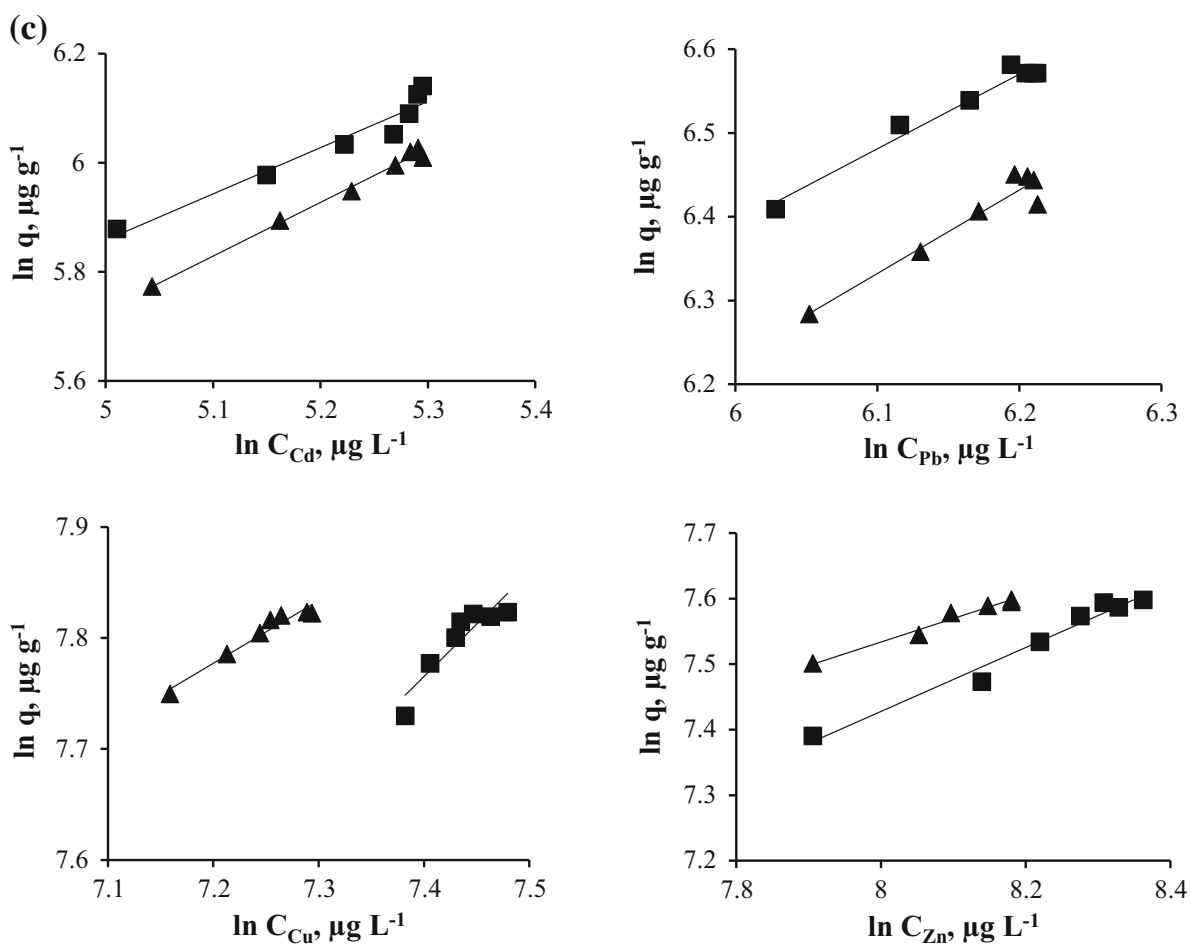

Table 3 Parameters for plotting Freundlich adsorption isotherms of selected heavy metals on biochar

\begin{tabular}{|c|c|c|c|c|c|c|c|}
\hline \multirow[t]{2}{*}{$\begin{array}{l}\text { Concentration of heavy metal ions in leaching } \\
\text { solution }\end{array}$} & \multirow[t]{2}{*}{ Adsorbent } & \multirow[t]{2}{*}{ Adsorbate } & \multicolumn{4}{|c|}{$\begin{array}{l}\text { Estimated parameters of } \\
\text { Freundlich isotherm }\end{array}$} & \multirow[t]{2}{*}{$R^{2}$} \\
\hline & & & $1 / n$ & $n$ & $\ln K$ & $K$ & \\
\hline \multirow[t]{8}{*}{ Onefold value of MCL } & \multirow{4}{*}{$\begin{array}{l}\text { Scots pine (Pinus sylvestris L.) } \\
\text { biochar }\end{array}$} & $\mathrm{Cd}(\mathrm{II})$ & 0.905 & 1.105 & 1.178 & 3.249 & 0.947 \\
\hline & & $\mathrm{Pb}(\mathrm{II})$ & 0.989 & 1.012 & 1.071 & 2.919 & 0.969 \\
\hline & & $\mathrm{Cu}(\mathrm{II})$ & 0.801 & 1.248 & 0.620 & 1.859 & 0.993 \\
\hline & & $\mathrm{Zn}(\mathrm{II})$ & 0.436 & 2.293 & 2.642 & 14.034 & 0.987 \\
\hline & \multirow{4}{*}{$\begin{array}{l}\text { Silver birch (Betula pendula) } \\
\text { biochar }\end{array}$} & $\mathrm{Cd}(\mathrm{II})$ & 0.962 & 1.039 & 1.592 & 4.911 & 0.991 \\
\hline & & $\mathrm{Pb}(\mathrm{II})$ & 0.939 & 1.065 & 1.502 & 4.490 & 0.991 \\
\hline & & $\mathrm{Cu}(\mathrm{II})$ & 0.278 & 3.600 & 4.065 & 58.236 & 0.993 \\
\hline & & $\mathrm{Zn}(\mathrm{II})$ & 0.343 & 2.917 & 3.246 & 25.682 & 0.995 \\
\hline \multirow[t]{8}{*}{ Twofold value of MCL } & \multirow[t]{4}{*}{ Scots pine ( $P$. sylvestris L.) biochar } & $\mathrm{Cd}(\mathrm{II})$ & 0.786 & 1.272 & 1.683 & 5.382 & 0.973 \\
\hline & & $\mathrm{Pb}(\mathrm{II})$ & 0.866 & 1.155 & 1.326 & 3.765 & 0.972 \\
\hline & & $\mathrm{Cu}(\mathrm{II})$ & 0.894 & 1.118 & 0.834 & 2.302 & 0.987 \\
\hline & & $\mathrm{Zn}(\mathrm{II})$ & 0.477 & 2.095 & 3.145 & 23.222 & 0.914 \\
\hline & \multirow[t]{4}{*}{ Silver birch (B. pendula) biochar } & $\mathrm{Cd}(\mathrm{II})$ & 0.887 & 1.128 & 1.655 & 5.233 & 0.956 \\
\hline & & $\mathrm{Pb}(\mathrm{II})$ & 0.974 & 1.026 & 0.861 & 2.365 & 0.985 \\
\hline & & $\mathrm{Cu}(\mathrm{II})$ & 0.283 & 3.535 & 4.858 & 128.715 & 0.969 \\
\hline & & $\mathrm{Zn}(\mathrm{II})$ & 0.863 & 1.159 & 0.033 & 1.034 & 0.924 \\
\hline \multirow[t]{8}{*}{ Fivefold value of MCL } & \multirow[t]{4}{*}{ Scots pine ( $P$. sylvestris L.) biochar } & $\mathrm{Cd}(\mathrm{II})$ & 0.987 & 1.013 & 0.796 & 2.216 & 0.992 \\
\hline & & $\mathrm{Pb}(\mathrm{II})$ & 0.997 & 1.004 & 0.254 & 1.289 & 0.932 \\
\hline & & $\mathrm{Cu}(\mathrm{II})$ & 0.564 & 1.773 & 3.716 & 41.087 & 0.950 \\
\hline & & $\mathrm{Zn}(\mathrm{II})$ & 0.358 & 2.796 & 4.673 & 107.018 & 0.976 \\
\hline & \multirow[t]{4}{*}{ Silver birch (B. pendula) biochar } & $\mathrm{Cd}(\mathrm{II})$ & 0.848 & 1.179 & 1.618 & 5.042 & 0.940 \\
\hline & & $\mathrm{Pb}(\mathrm{II})$ & 0.891 & 1.122 & 1.046 & 2.846 & 0.969 \\
\hline & & $\mathrm{Cu}(\mathrm{II})$ & 0.942 & 1.061 & 0.792 & 2.208 & 0.832 \\
\hline & & $\mathrm{Zn}(\mathrm{II})$ & 0.488 & 2.049 & 3.532 & 34.203 & 0.972 \\
\hline
\end{tabular}



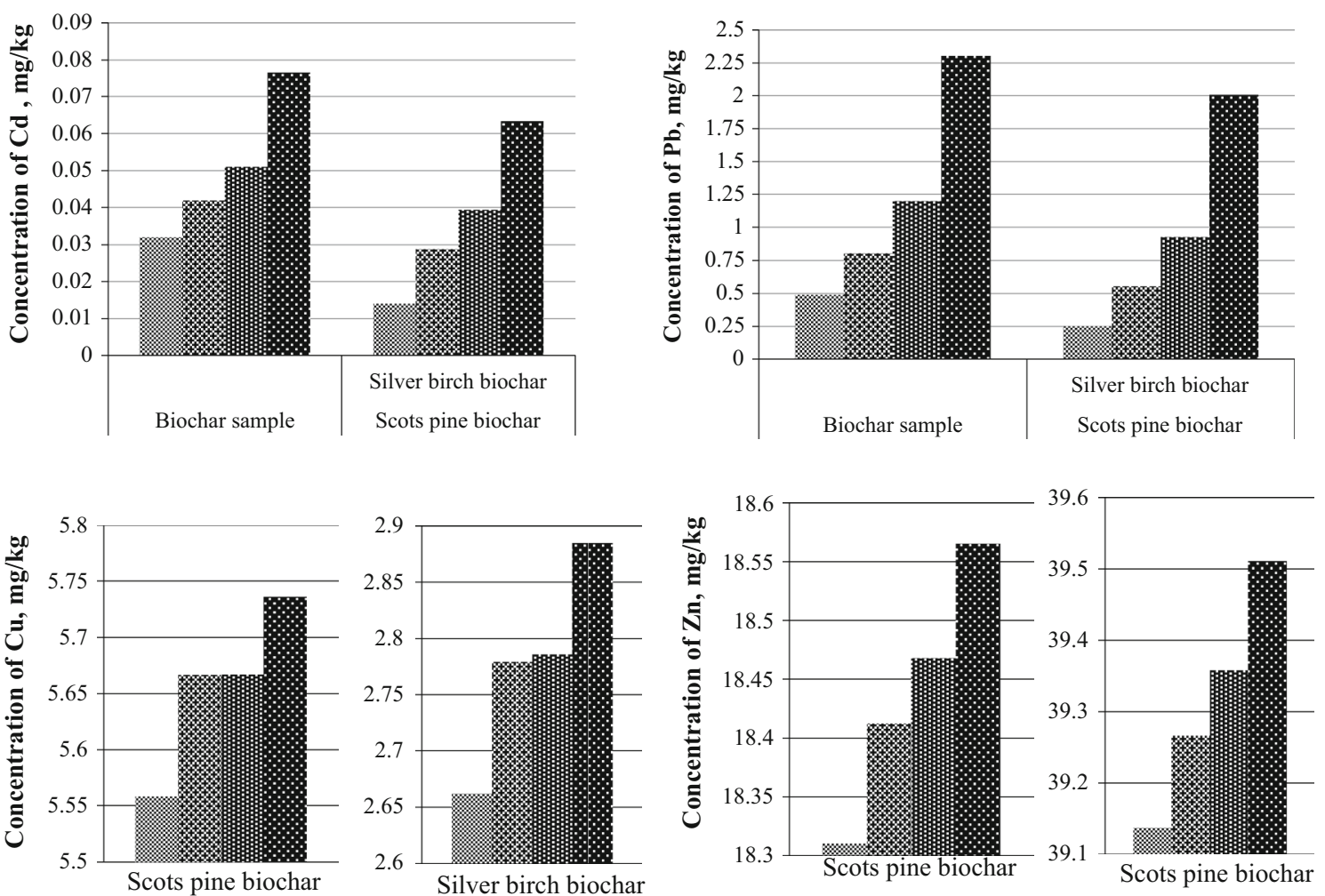

: Before adsorption

After adsorption of heavy metals ions with 1-fold MCL

盯 After adsorption of heavy metals ions with 2-fold MCL

- After adsorption of heavy metals ions with 5-fold MCL

Fig. 7 Concentration of heavy metals $(\mathrm{Cd}, \mathrm{Pb}, \mathrm{Cu}, \mathrm{Zn})$ in biochar samples before and after adsorption

worst, while the adsorption of $\mathrm{Pb}$ (II) and $\mathrm{Zn}$ (II) on both types of biochar interchangeably varied due to different size of pores of biochar.

Determined concentrations of selected heavy metals in biochar samples are shown in Fig. 7. The difference between amounts of heavy metals in leaching solutions and eluate match the adsorbed amounts of heavy metals in biochar.

The concentrations of heavy metals in biochar samples before and after the application of adsorption satisfied the premium thresholds $\left(\mathrm{Cd}<1 \mathrm{~g} \mathrm{t}^{-1} ; \quad \mathrm{Pb}<120 \mathrm{~g} \mathrm{t}^{-1}\right.$; $\mathrm{Cu}<100 \mathrm{~g} \mathrm{t}^{-1} ; \mathrm{Zn}<400 \mathrm{~g} \mathrm{t}^{-1}$ ) defined in European Biochar Certificate (European Biochar Foundation 2011), so biochar can be applied again or reused for other purposes such as improvement of agricultural soil, soil rehabilitation in the contaminated sites, and energy production.

Due to statistical reliability, the extended Freundlich expressions can be recommended for evaluation of adsorption of heavy metals on Silver birch and Scots pine biochar in the stream of storm water runoff. Heavy metal ions removal efficiency of 35-37 \% on Silver birch biochar can be taking into account projecting facilities for treatment of the metal-polluted water.

\section{Conclusion}

Due to advantageous physical and chemical characteristics (such as porous network and cation exchange capacity) of biochar, the interest towards adsorption processes and efficiency of various pollutants on different types of biochar has increased in recent years. Current work indicated the opportunity to treat efficiently metal-contaminated water by adsorption onto biochars of Silver birch and Scots pine.

Due to higher $\mathrm{pH}$ of Scots pine biochar, $\mathrm{pH}$ of eluate resulted from elution through Silver birch biochar slightly increased more than $\mathrm{pH}$ of eluate resulted from elution through Scots pine biochar. The attention should be focused on highly alkaline biochar, which could increase $\mathrm{pH}$ of treating water above the limits.

Adsorption efficiency of both types of biochar decreased with increased initial concentration of heavy metals ions. The adsorption of heavy metal ions increased, when the dosage of adsorbent increased. The capacity and intensity with which biochar adsorbed heavy metal ions from leaching solution had been modelled by the application of 
extended Freundlich isotherm. It reflected the heterogeneous properties of the surfaces and favourable adsorption process.

Acknowledgments This work was partly supported by project "Promotion of Student Scientific Activities" (VP1-3.1-ŠMM-01-V02-003) from the Research Council of Lithuania. This project is funded by the Republic of Lithuania and European Social Fund under the 2007-2013 Human Resources Development Operational Programme's priority.

\section{References}

Adedeji OH, Olayinka OO (2013) Heavy metal concentrations in urban storm water runoff and receiving stream. J Environ Earth Sci 3(7):141-150

Aston S, Doerr S, Street-Perrott A (2013) The impacts of pyrolysis temperature and feedstock type on biochar properties and the effects of biochar application on the properties of a sandy loam. In: EGU general assembly. Vienna, Austria, Saturday 7th to Friday 12th April 2013. Vienna. Geophys Res Abstr, vol 15, pp 11-83

Babel S, Kurniawan TA (2003) Low-cost adsorbents for heavy metals uptake from contaminated water: a review. J Hazard Mater 97(1-3):219-243

Baltrenas P, Vaitkute D (2011) Investigation and evaluation of copper and zinc concentration tendencies in Pinus sylvestris L. treerings. J Environ Eng Landsc Manag 19(4):278-286

Baltrenas P, inventor; Butkus D, inventor; Baltrenaite E, inventor (2006) Vilnius Gediminas Technical University, assignee. Sunkiụju metalụ koncentracijos nustatymo metineje medienos rieveje būdas [Method of determination of heavy metal concentrations in the annual wood ring] Lithuania patent LT 5325 B. 2006 Mar 27

Brownsort PA (2009) Biomass pyrolysis processes: performance parameters and their influence on biochar system benefits. UK Biochar Research Centre - SCCS Consortium, Edinburgh

Bruun EW (2011) Application of fast pyrolysis biochar to a loamy soil. Ris $\emptyset$ National Laboratory for Sustainable Energy, Roskilde

Dada AO, Ojediran JO, Olalekan AP (2013) Sorption of $\mathrm{Pb}^{+2}$ from aqueous solution unto modified rice husk: isotherm studies. Adv Chem Phys 2013:9-103

Desta MB (2013) Batch sorption experiments: Langmuir and Freundlich isotherm studies for the adsorption of textile metal ions onto Teff Straw (Eragrostis tef) agricultural waste. J Thermodyn 2013:64-71, Art ID 375830

Downie A, Crosky A, Munroe P (2009) Physical properties of biochar. In: Lehmann J, Joseph $\mathrm{S}$ (eds) Biochar for environmental management: science and technology. Earthscan, London, pp 13-32

Eiviene R, Tricys V (2011) Research on pollution in precipitation in Siauliai. J Young Sci 3(32):119-124

European Biochar Foundation (2011) European biochar certificateguidelines for a sustainable production of biochar. http://www. european-biochar.org/en. Accessed 12 Apr 2014

Filgueiras AV, Lavilla Bendicho C (2004) Evaluation of distribution, mobility and binding behaviour of heavy metals in surficial sediments of Louro River (Galicia, Spain) using chemometric analysis: a case study. Sci Total Environ 330:115-129

Förster J (1999) Variability of roof runoff quality. Water Sci Technol 39(5):137-144

Giesche H (2006) Mercury porosimetry: a general (practical) overview. Part Part Syst Char 23:1-11
Glaser B, Haumaier L, Guggenberger G, Zech W (2001) The Terra Preta phenomenon: a model for sustainable agriculture in the humid tropics. Naturwissenschaften 88:37-41

Glass SV, Zelinka SL (2010) Moisture relations and physical properties of wood. http://www.fpl.fs.fed.us/documnts/fplgtr/ fplgtr190/chapter_04.pdf. Accessed 12 Apr 2014

Göbel P, Dierkes C, Coldewey WG (2007) Storm water runoff concentration matrix for urban areas. J Contam Hydrol 91:26-42

Goldberg S (2005) Equations and models describing adsorption processes in soils. In: Tabatabai MA, Sparks DA (eds) Chemical processes in soils. Soil Science Society of America, Madison, pp 489-517

Hvitved-Jacobsen T, Vollertsen J, Nielsen AH (2009) Urban and highway stormwater pollution. CRC Press, New York

Kaminskas M (2012) Vilniaus miesto paviršinio vandens stebèsena (monitoringas). 2011-2012 metụ tyrimụ rezultatai [The results of 2011-2012 surface water monitoring of Vilnius city]. http:// aplinka.vilnius.lt/lt/wp-content/uploads/2013/03/Vilniauspavirsinio-vandens-monitoringas-2011-12.pdf. Accessed 12 Apr 2014

Kathleen AD, Janecek T, Klaus A (1992) Dry-bulk density: its use and determination. Proc Ocean Drill Progr Sci Results 126:551-554

Kennish MJ (1992) Ecology of estuaries: anthropogenic effects. CRC Press, New York

Kuang X, Sansalone J (2011) Cementitious porous pavement in stormwater quality control: $\mathrm{pH}$ and alkalinity elevation. Water Sci Technol 63(12):2992-2998

Laird D, Rogovska NP, Garcia-Perez M, Collins HP, Streubel JD, Smith M (2011) Pyrolysis and biochar-opportunities for distributed production and soil quality enhancement. In: Braun R, Karlen D, Johnson D (eds) Sustainable alternative fuel feedstock opportunities, challenges and roadmaps for six U.S. Regions. Soil and Water Conservation Society, Atlanta, pp 257-281

Lehman J, Rillig MC, Thies J, Masiello CA, Hockaday WC, Crowley D (2011) Biochar effects on soil biota-a review. Soil Biol Biochem 43:1812-1836

Liang B, Lehmann J, Solomon D, Kinyangi J, Grossman J, O’Neill B, Skjemstad O, Thies J, Luizao FJ, Petersen J, Neves EG (2006) Black carbon increases cation exchange capacity in soils. Soil Sci Soc Am J 70:1719-1730

Lin SH (1993) Adsorption of disperse dye by various adsorbents. J Chem Tech Biotechnol 58(2):107-210

Low KS, Lee CS (2000) Sorption of cadmium and lead from aqueous solutions by spent grain. J Process Biochem 36:59-64

McGeer J, Henningsen G, Lanno R, Fisher N, Sappington K, Drexler J (2004) Issue paper on bioavailability and bioaccumulation of metals. Eastern Research Group, Lexington

Mihaljevic M, Sisr L, Ettler V, Sebek O, Prusa J (2004) Oxidation of As-bearing gold ore-a comparison of batch and column experiments. J Geochem Explor 81:59-70

Milukaite A, Sakalys J, Kvietkus K, Vosyliene M, Kazlauskiene N, Karlaviciene V (2010) Physico-chemical and ecotoxicological characterizations of urban storm water runoff. Pol J Environ Stud 19(6):1279-1285

Mohan S, Karthikeyan J (1997) Removal of lignin and tannin color from aqueous solution by adsorption on to activated carbon solution by adsorption on to activated charcoal. Environ Pollut 97:183-187

Muthukrishnan S (2006) Treatment of heavy metals in stormwater runoff using wet pond and wetland mesocosms. http:// scholarworks.umass.edu/cgi/viewcontent.cgi?article= 1083\&context=soilsproceedings. Accessed 12 Apr 2014

Nguyen B, Lehmann J (2009) Black carbon decomposition under varying water regimes. Org Geochem 40:846-853 
Nigussie A, Kissi E, Misganaw M, Ambaw G (2012) Effect of biochar application on soil properties and nutrient uptake of lettuces (Lactuca sativa) grown in chromium polluted soils. Am Eurasian J Agric Environ Sci 12(3):369-376

Novotny V, Olem H (1994) Water quality: prevention, identification, and management of diffuse pollution. Van Nostrand Reinhold, New York

Overend RP (2008) Thermochemical conversion of biomass. http:// www.eolss.net/sample-chapters/c08/e3-08-01-05.pdf. Accessed 29 Sep 2014

Pundyte N, Baltrenaite E, Pereira P, Paliulis D (2011) Anthropogenic effects on heavy metals and macronutrients accumulation in soil and wood of Pinus sylvestris L. J Environ Eng Landsc Manag 19(1):34-43

Sadaka S, Negi S (2009) Improvements of biomass physical and thermochemical characteristics via torrefaction process. Environ Prog Sustain Energy 28(3):427-434
Saleh ME, Mahmoud AH, Rashad M (2012) Peanut biochar as a stable adsorbent for removing $\mathrm{NH}_{4}-\mathrm{N}$ from wastewater: preliminary study. Adv Environ Biol 6(7):2170-2176

Shareef KM (2009) Sorbents for contaminant uptake from aqueous solution. Part I: heavy metals. World J Agric Sci 5(8):819-831

State Forest Service under the Ministry of Environment of Lithuania (2012) State forest accounting. http://www.amvmt.1t/20130101/ 20130101.aspx?\&MID=0\&AMID=747. Accessed 12 Apr 2014

Tan LL, Ahmad M, Lee YH (2012) A novel optical ammonia sensor based on reflectance measurements of highly polluted and coloured water. Sens Actuat B-Chem 171:994-1000

Thavamani SS, Rajkumar R (2013) Removal of $\mathrm{Cr}(\mathrm{II}), \mathrm{Pb}$ (II) and $\mathrm{Ni}(\mathrm{II})$ from aqueous solution by adsorption on alumina. Res $\mathrm{J}$ Chem Sci 3(8):44-48 